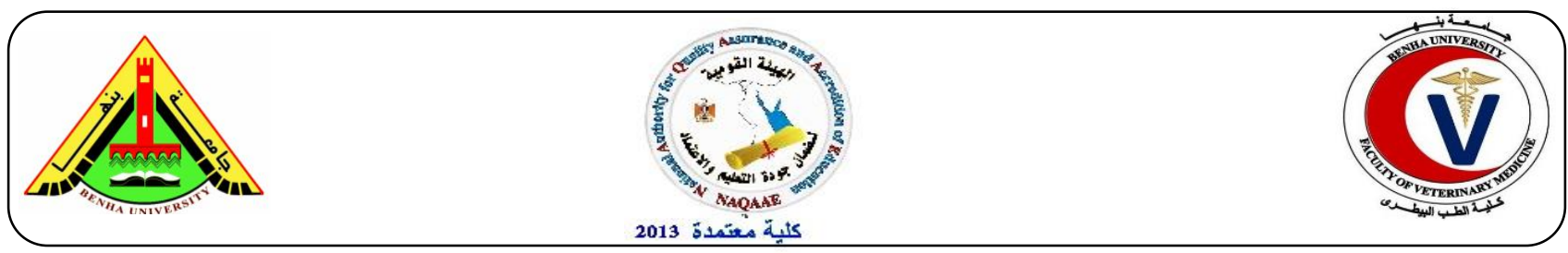

\title{
Hygienic Considerations of Pathogenic Escherichia Coli Contamination on Cattle Carcass Surfaces in Egypt
}

\author{
Saad Mahmoud Saad, Amani Mohamed Salem ${ }^{1}$, Shaimaa Nada ${ }^{2}$, Mohamed - Mona ${ }^{2}$ \\ ${ }^{1}$ Food Control Department. Faculty of Veterinary Medicine, Benha University \\ 2 Animal Health Research Institute "Shebine EL-Koom Branch".
}

\section{A B S T R A C T}

A total of 100 random samples were collected from surfaces of cattle carcasses in EL-Shouhada and Birket El -Sabaa Abattoirs in Menofyia governorate (50 of each). The results showed that the mean E. coli counts were $5.44 \times 10^{2}$ and $7.99 \times 10^{2} \mathrm{cfu} / \mathrm{cm}^{2}$ in EL- Shouhada and Birket EL-Sabaa abattoirs, respectively. Also, the incidence of $E$.coli isolated from cattle carcass surfaces in EL-Shouhada and Birket El-Sabaa abattoirs were $26 \%$ and $28 \%$, respectively. The isolated serotypes of $E$. coli were EHEC as $\mathrm{O}_{111}: \mathrm{H}_{2}(8 \%)$ and $\mathrm{O}_{26}: \mathrm{H}_{11}(2 \%)$, EPEC as $\mathrm{O}_{15}: \mathrm{H}_{4}(2 \%), \mathrm{O}_{55}: \mathrm{H}_{7}(2 \%), \mathrm{O}_{114}: \mathrm{H}_{4}(4 \%)$ and $\mathrm{O}_{146}: \mathrm{H}_{21}(2 \%)$, ETEC as $\mathrm{O}_{128}: \mathrm{H}_{2}(2 \%)$ and $\mathrm{O}_{125:} \mathrm{H}_{21}(2 \%)$ and EIEC as $\mathrm{O}_{124}(2 \%)$ in ELShouhada abattoirs, while in Birket EL-Sabaa abattoir were EHEC as $\mathrm{O}_{111}: \mathrm{H}_{2}(6 \%), \mathrm{O}_{26}: \mathrm{H}_{11}$ (8\%) and $\mathrm{O}_{103}: \mathrm{H}_{4}(2 \%)$, EPEC as $\mathrm{O}_{55}: \mathrm{H}_{7}(2 \%)$ and $\mathrm{O}_{91}: \mathrm{H}_{21}(2 \%)$ ETEC as $\mathrm{O}_{128}: \mathrm{H}_{2}(6 \%)$ and EIEC as $\mathrm{O}_{124}(2 \%)$. Findings of multiplex PCR showed that eaeA (intimin) gene was detected in $\left(\mathrm{O}_{91}: \mathrm{H}_{21}\right.$ and $\left.\mathrm{O}_{114}: \mathrm{H}_{4}\right)$, hlyA (haemolysin) gene was detected in $\left(\mathrm{O}_{125}: \mathrm{H}_{21}\right)$, stx 1 gene was not detected in the all isolated $E$. coli serogroups, but stx $_{2}$ gene was detected in $\left(\mathrm{O}_{26}: \mathrm{H}_{11}\right.$ and $\left.\mathrm{O}_{114}: \mathrm{H}_{4}\right)$.

Keywords: Escherichia Coli, Cattle Carcass, Menofyia governorate.

(http://www.bvmj.bu.edu.eg)

(BVMJ-34(1): 305-313, 2018)

\section{INTRODUCTION}

The sanitary conditions of abattoirs and their surrounding environment are major factors contributing in bacterial contamination of meat (Gill et al., 2000).

Escherichia coli infection is highly prevalent in abattoir environment, and can pose a major threat to human health in underdeveloped communities (Abu El nagaet al., 2014). Meanwhile, it is commonly non virulent but some strains have adapted pathogenic or toxigenic virulence factors that make them virulent for humans and animals (Malik and Memona, 2010). It is also commonly used as surrogate indicator; its presence in food generally indicates direct and indirect fecal contamination (Clarence et al., 2009).

Shiga-toxin producing E. coli (STEC) were found in a wide variety of animal species, including cattle, sheep, goats, pigs, water buffalos and wild ruminants (Caprioli et al., 2005). Cattle form the main reservoir of (STEC) and fecal contamination of food represents the usual source of infection for humans but due to an apparently low infectious dose, human to human transmission 
was also observed in outbreaks (Kuhnert et al., 2000). Pathogenic strains of E. coli were divided into intestinal pathogenic E.coli (INPEC) causing diarrhea and extraintestinal pathogenic E.coli (EXPEC) including urinary tract infection (UTI), meningitis and septicemia depend on virulence factors and clinical symptoms (Kaper et al., 2004 and Eid and Erfan, 2013).

Polymerase Chain Reaction (PCR) based methods were identified as a powerful diagnostic tool for the detection of pathogenic microorganisms (Malorny et al., 2003). Compared to other methods of detection, these methods were rapid, highly specific and sensitive in the identification of target organisms (Wang et al., 2007).

\section{Materials and methods}

\subsection{Collection of samples:}

A total of 100 random samples were collected from surfaces of cattle carcasses slaughtered in EL-Shouhada and Birket El Sabaa abattoirs (50 of each) in Menofyia governorate. The samples were taken using swab technique under aseptic conditions, just after washing and before stamping. The collected samples (Swabs) were preserved in an ice box then transferred to laboratory without undue delay and subjected to the microbiological examination.

r.2. Preparation of templates and Swabbing (FSIS, USDA., 1996)

A templates made of metal having an exposed inner area $10 \mathrm{~cm}^{2}(2 \times 5 \mathrm{~cm})$ was used to delineate area of sampling.

Swabs from cattle carcasses surfaces were taken by using sterile cotton swabs and templates. The sterilized templates were placed firmly against the surface of examination to limit the examined area. The sterile cotton swab was rolled over the limited area inside the template, rolled in one direction and perpendicular to this direction to represent all the examined area. Finally, the cotton swabs were aseptically retained into the rinsing fluid screw capped tubes containing $10 \mathrm{ml}$ buffered peptone water $(0.1 \%)$.

\subsection{Preparation of swabs (APHA, 2001):}

The collected swabs were mixed in $225 \mathrm{ml}$ of sterile buffered peptone water $(0.1 \%)$ to give $1 / 10$ dilution. One $\mathrm{ml}$ from the original dilution was transferred with sterile pipette to another sterile test tube containing $9 \mathrm{ml}$ of buffered peptone water and mixed well to make the next dilution, from which further decimal serial dilutions were prepared.

2.4. Detection of E. coli count was done according to McFadden (2000).

2.5. Isolation and identification of Escherichia coli was done according to McFadden (2000).

\subsection{Serological identification of E. coli}

The isolates were serologically identified according to Kok et al. (1996) by using rapid diagnostic E.coli antisera sets (DENKA SEIKEN Co., Japan).

2.7. Polymerase Chain Reaction (PCR):

2.7.1. Extraction of DNA

2.7.2. Preparation of PCR Master Mix

2.7.3. Cycling conditions of the primers during $c P C R$

2.7.4. DNA Molecular weight marker

2.7.5 Agarose gel electrophoreses

\section{RESULTS}

The results in table (1) revealed that the mean of $E$. coli counts were $5.44 \times 10^{2} \pm 1.13^{\mathrm{a}}$ and $7.99 \times 10^{2} \pm 1.13^{\mathrm{A}}$ in EL-Shouhada and Birket El-Sabaa abattoir, respectively. On the other hand, the results in Table (3) showed that the incidence of $E$. coli in the examined swab samples was $(26 \%)$ and $(28 \%)$ in ELShouhada and Birket EL-Sabaa abattoirs, respectively. Also, it is obvious from the results achieved in Table (5) that the serological identified $E$. coli serotypes were EHEC as $\mathrm{O}_{111}: \mathrm{H}_{2}(8 \%)$ and $\mathrm{O}_{26}: \mathrm{H}_{11}(2 \%)$, 
EPEC as $\mathrm{O}_{15}: \mathrm{H}_{4}(2 \%), \mathrm{O}_{55}: \mathrm{H}_{7}(2 \%), \mathrm{O}_{114}$ : $\mathrm{H}_{4}(4 \%)$ and $\mathrm{O}_{146}: \mathrm{H}_{21}(2 \%)$, ETEC as $\mathrm{O}_{128}$ : $\mathrm{H}_{2}(2 \%)$ and $\mathrm{O}_{125}: \mathrm{H}_{21}(2 \%)$ and EIEC as $\mathrm{O}_{124}$ $(2 \%)$ in EL-Shouhada abattoir. Meanwhile in Birket El-Sabaa abattoir, EHEC as $\mathrm{O}_{111}: \mathrm{H}_{2}$ $(6 \%), \mathrm{O}_{26}: \mathrm{H}_{11}(8 \%)$ and $\mathrm{O}_{103}: \mathrm{H}_{4}(2 \%)$, EPEC as $\mathrm{O}_{55}: \mathrm{H}_{7}(2 \%)$ and $\mathrm{O}_{91}: \mathrm{H}_{21}(2 \%)$ ETEC as $\mathrm{O}_{128}: \mathrm{H}_{2}(6 \%)$ and EIEC as $\mathrm{O}_{124}$
(2\%). While, the results in Table (6) showed that the eaeA (intimin or E. coli attaching and effacing) gene was detected in $\left(\mathrm{O}_{91}: \mathrm{H}_{21}\right.$ and $\mathrm{O}_{114}: \mathrm{H}_{4}$ ), hlyA (haemolysin) gene was detected in $\left(\mathrm{O}_{125}: \mathrm{H}_{21}\right)$, stx 1 gene was not detected in the all isolated E. coli serogroups, but $s t x_{2}$ gene was detected in $\left(\mathrm{O}_{26}: \mathrm{H}_{11}\right.$ and $\mathrm{O}_{114}: \mathrm{H}_{4}$

Table (1): Mean values of $E$. coli count $\left(\mathrm{cfu} / \mathrm{cm}^{2}\right)$ in swab of cattle carcass surfaces from abattoirs in Menofyia governorate $(\mathrm{n}=50)$.

Abattoirs

\section{Abattoirs}

(20)

EL- Shouhada

$1.82 \times 10^{2}$

$4.07 \times 10^{3}$

$5.44 \times 10^{2} \pm 1.13^{\mathrm{a}}$

Birket El-Sabaa

$$
2.29 \times 10^{2}
$$

$6.31 \times 10^{3}$

$7.99 \times 10^{2} \pm 1.13^{\mathrm{A}}$

\section{S.E $E^{*}=$ Standard error of mean}

Table (2): Analysis of variance (ANOVA) of E. coli count in swab of cattle carcass surfaces from abattoirs in Menofyia governorate $(n=50)$.

\begin{tabular}{|l|l|l|l|l|l|}
\hline $\begin{array}{l}\text { Source } \\
\text { Variance }\end{array}$ & S.S. & D.F. & M.S. & F. value & Sig. \\
\hline Between Groups & 694 & 1 & .694 & 4.729 & .032 \\
Within Groups & 14.380 & 98 & .147 & & \\
Total & 15.074 & 99 & & & \\
\hline
\end{tabular}

D.F $=$ Degrees of freedom, $S . S=$ Sum squares, M.S = Mean squares, = significant differences $(\mathrm{P}<0.05)$

Table (3): Incidence of $E$. coli in the examined swab of cattle carcass surfaces from abattoirs in Menofyia governorate $(\mathrm{n}=50)$.

\section{Positive samples}

Abattoir

\begin{tabular}{lll} 
& NO. & $\%$ \\
\hline EL- Shouhada & 13 & 26 \\
Birket El-Saba & 14 & 28 \\
Total & 27 & 54 \\
\hline
\end{tabular}


Table (4): Serotypes of E. coli in the examined swab of cattle carcass surfaces from abattoirs in Menofyia governorate $(\mathrm{n}=50)$.

\begin{tabular}{|c|c|c|c|c|c|}
\hline \multirow{2}{*}{$\begin{array}{l}\text { Swabs } \\
\text { Strains }\end{array}$} & \multicolumn{2}{|c|}{ EL- Shouhada abattoir } & \multicolumn{2}{|c|}{$\begin{array}{l}\text { Birket-El-Sabaa } \\
\text { abattoir }\end{array}$} & \multirow{2}{*}{ Strain Characteristics } \\
\hline & No. & $\%$ & No. & $\%$ & \\
\hline $\mathrm{O} 111: \mathrm{H} 2$ & 4 & 8 & 3 & 6 & \\
\hline O26 : H11 & 1 & 2 & 4 & 8 & EHEC \\
\hline O103 : H4 & - & - & 1 & 2 & \\
\hline $\mathrm{O} 15: \mathrm{H} 4$ & 1 & 2 & - & - & \\
\hline O55 : H7 & 1 & 2 & 1 & 2 & \\
\hline O114 : H4 & 2 & 4 & - & - & \\
\hline O146 : H21 & 1 & 2 & - & - & EPEC \\
\hline O91 : H21 & - & - & 1 & 2 & \\
\hline $\mathrm{O} 128: \mathrm{H} 2$ & 1 & 2 & 3 & 6 & \\
\hline O125 : H21 & 1 & 2 & - & - & ETEC \\
\hline $\mathrm{O} 124$ & 1 & 2 & 1 & 2 & EIEC \\
\hline Total & 13 & 26 & 14 & 28 & \\
\hline
\end{tabular}

Table (5): The results of PCR amplifications of different used genes of E. coli serogroups:

\begin{tabular}{lllll} 
& Results & & \\
Sample & EaeA & HlyA & Stxl & Stx2 \\
\hline $1\left(\mathrm{O}_{15}: \mathrm{H}_{4}\right)$ & - & - & - & - \\
$2\left(\mathrm{O}_{26}: \mathrm{H}_{11}\right)$ & - & - & - & + \\
$3\left(\mathrm{O}_{55}: \mathrm{H}_{7}\right)$ & - & - & - & - \\
$4\left(\mathrm{O}_{91}: \mathrm{H}_{21}\right)$ & + & - & - & - \\
$5\left(\mathrm{O}_{103}: \mathrm{H}_{4}\right)$ & - & - & - & - \\
$6\left(\mathrm{O}_{111}: \mathrm{H}_{2}\right)$ & - & - & - & - \\
$7\left(\mathrm{O}_{114}: \mathrm{H}_{4}\right)$ & + & - & - & + \\
$8\left(\mathrm{O}_{124}\right)$ & - & - & - & - \\
$9\left(\mathrm{O}_{125}: \mathrm{H}_{21}\right)$ & - & + & - & - \\
$10\left(\mathrm{O}_{128}: \mathrm{H}_{2}\right)$ & - & - & - & - \\
$11\left(\mathrm{O}_{146}: \mathrm{H}_{21}\right)$ & - & - & - & -
\end{tabular}




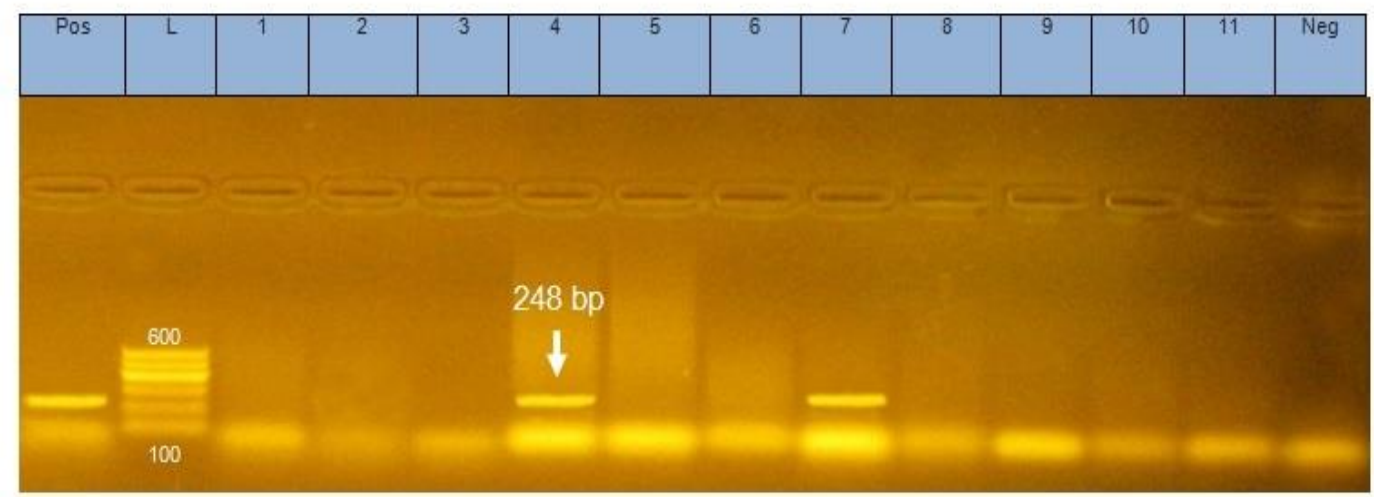

Figure (1): Agarose gel electrophoresis of PCR amplification products using specific primers of (eaeA) gene of E. coli. Lane L: 100-600bp DNA Ladder. Pos.: control Positive at (248bp). Neg.: control Negative. Lane1,2,3,5,6,8,9,10,11(Negative). Lane 4, 7 (Positive).

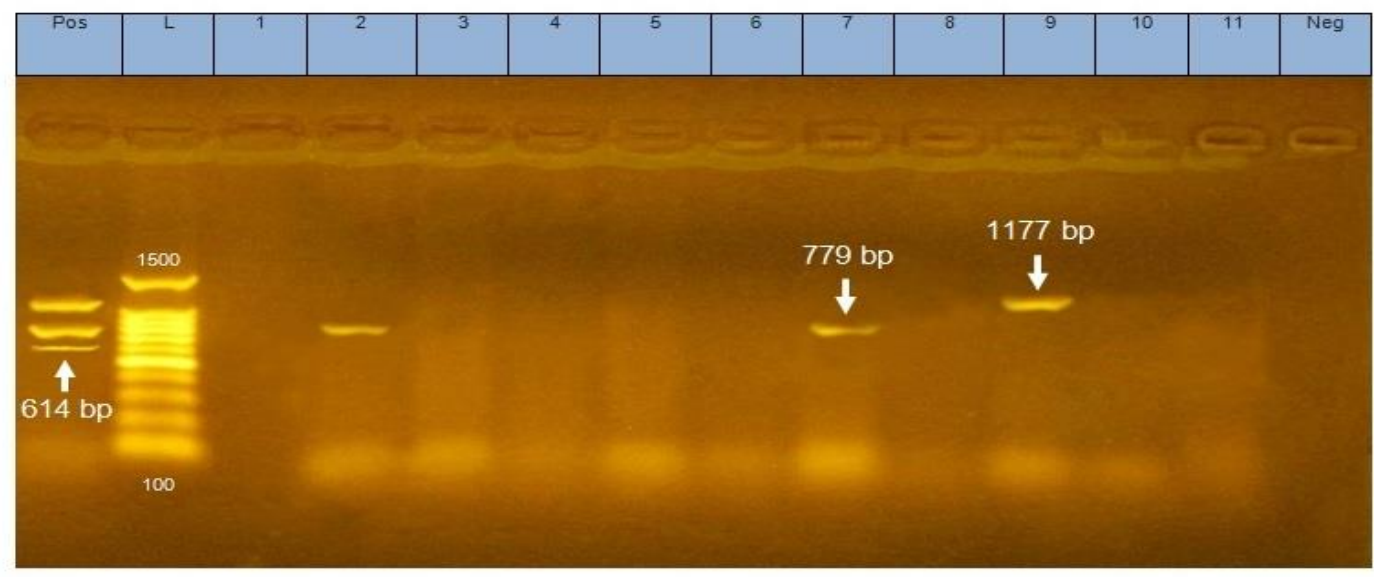

Figure (2): Agarose gel electrophoresis of PCR amplification products using specific primers of (stx1) gene, (stx2) gene and (hlyA) gene of E.coli.

*hlyA : Haemolysin gene. Lane L: 100-1500bp DNA Ladder. Pos.: control Positive (at 1177bp). Neg.: control Negative. Lane 9 (Positive). Lane 1,2,3,4,5,6,7,8,10,11 (Negative). *Stx 1 : Shiga toxin1gene.Pos.: control Positive(at 614bp). Lane 1,2,3,4,5,6,7,8,9,10,11(Negative).

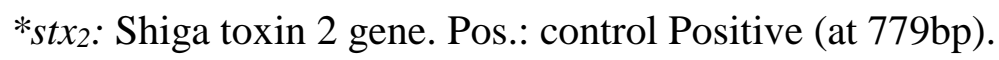

Lane 1,3,4,5,6,8,9,10,11(Negative). Lane 2, 7 (positive).

\section{DISCUSSION}

Foodborne illnesses caused by E. coli represent a major public health problem worldwide. Every treatment done to meat from the point of slaughtering until it is ready for consumption could add to the bacterial load of this meat. Thus, meat products are considered as a major vehicle of most reported foodborne outbreaks, and may be contaminated with several types of organisms through long chain of preparation, handling of raw meat, processing, distribution, storage and retailing (Shawish, 2015).

The results recorded in Table (1) were similar with those reported by Bello et al., (2011) (4.6 Log to 4.9 Log $\mathrm{cfu} / \mathrm{cm}^{2}$ ), Ahmad (2013) (2.81 $\left.\log \mathrm{cfu} / \mathrm{cm}^{2}\right)$ and Eugène (2013) (0.8 to $3.0 \log \mathrm{cfu} / \mathrm{g}$ ). On the other hand, higher ones were recorded by EL-Morsi 
(1994) $\left(39 \times 10^{2} \mathrm{cfu} / \mathrm{cm}^{2}\right)$ and Bogere, P. and Baluka, A. S. (2014) $\left(8.4 \times 10^{4} \mathrm{cfu} / \mathrm{g}\right)$. While, lower ones obtained by Fliss et al. (1991) $\left(0.15 \times 10^{2}\right.$ organisms $\left./ \mathrm{cm}^{2}\right)$ and David et al. (2006) (0.8 $\left.\log \mathrm{cfu} / \mathrm{cm}^{2}\right)$. The results obtained in Table (3) nearly agreed with Moustafa (1993) (34\%), Barkocy-Gallagher et al. (2003) (26.7\%) and Abdelrahman- Alromisaa (2015) (25\%). On the other hand, higher incidence were obtained by EL-Bassiouny and Samaha (1991) (80\%), Nashid-Heba (1993) (48\%), Enabulele and Uraih (2009) (100\%) and Bogere and Baluka (2014) $(83.3 \%)$. While, lower incidence was obtained by Hassouba (2000) (17.2\%), Abdallah et al. (2009b) (8.86\%). The variation in the results between counts and incidences of $E$. coli in the examined swab samples of cattle carcass surfaces between both of EL-Shouhada and Birket EL-Sabaa abattoirs was attributed to the differences in slaughtering, preparation, handling and the effectiveness of hygienic measures applied in these abattoirs. It is obvious from the results recorded in Table (5) that they were nearly similar to those obtained by Moustafa (1993) $\left(\mathrm{O}_{26}, \mathrm{O}_{55}, \mathrm{O}_{111}\right.$ and $\left.\mathrm{O}_{124}\right)$, Abdelrahman- Alromisaa (2015) $\left(\mathrm{O}_{128}: \mathrm{H}_{2}\right.$, $\mathrm{O}_{124}$ andO $26: \mathrm{H}_{11}$ ) and Ismail-Eman (2015) $\left(\mathrm{O}_{26}: \mathrm{H}_{11}\right.$ and $\left.\mathrm{O}_{128}: \mathrm{H}_{2}\right)$, while Barlow et al. (2006) could not isolated $\left(\mathrm{O}_{26}\right.$ and $\left.\mathrm{O}_{111}\right)$, while Abdallah (2009) isolate $\left(\mathrm{O}_{78}\right.$ and $\mathrm{O}_{86}$ ). The results in Table (7) and Fig (2) of PCR amplification of $S_{t} x_{2}$ gene substantiated what was reported by Adrienne and James (1998), Ram et al. (2007) and Fernández et al. (2010). Meanwhile, the results in Table (7) and Fig (1) of PCR amplification of intimin gene were nearly agreed with those obtained by Adrienne and James (1998), Ram et al. (2007). Finally, PCR amplification of HlyA gene in examined isolates in Table (7) and Fig (2) substantiated what was reported by Adrienne and James (1998) and Wang et al. (2013).
As conclusion, the examined swab samples recovered from surfaces of carcasses slaughtered at both abattoirs were contaminated by pathogenic E. coli, but there was a highly incidence in samples which were collected from Birket EL-Sabaa abattoir than those from EL-Shouhada one. This conclusion was attributed to the differences in effective hygienic measures adopted in both abattoirs.

\section{REFERENCES}

Abdallah, F. A. 2009. Prevalence of Enterobacteriaceae in cattle carcasses with special reference to pathogenic Escherichia coli. MVSc. thesis (Meat Hygiene), Fac. Vet. Med., Zagazig Univ., Egypt.

Abdallah, M.A., Suliman, S.E., Ahmed, D.E., Bakhiet, A.O. 2009b. Estimation of bacterial contamination of indigenous bovine carcasses in Khartoum (Sudan).Afri. J. Microbiol. Res., 3(12): 882- 886.

Abdelrahman-Alromisaa, A. M. E. 2015. Enteropathogenic E. coli in some slaughtered animals. M.V.Sc. Thesis (Meat Hygiene), Fac. Vet. Med., Zagazig, Univ., Egypt.

Abu El Naga, Azza; S. M., Hedia, Riham H., Ata, Nagwa S., Zaki, Mona. S. 2014. Bacterial aspect of Food Poisoning. Life Sci. J., 11(3):290-298.

Adrienne, W.P., James, C.P. 1998. Detection and characterization of shiga toxigenic Escherichia coli by using multiplex PCR assay for stx 1 , stx 2 , eae $A$, Enterohemorrhagic E. coli hlyA rfbO111 and $r f b O 157$. J. of Clinical Microbiol., 36(2): 598-602. 
Ahmad, M. U. D., Safwat, A., Najeeb, M. I., Nawaz, M., Anjum, A. A., Ali, M. A., Mansur, N. 2013. Assessment of microbial load of raw meat at abattoirs and retail outlets. The J. of Animal and Plant Sciences, 23(3): 745-748 .

American Public Health Association "APHA" $2001 . \quad$ Compendium of methods for microbiological examination of foods. $4^{\text {th }}$ Edition 365 366-800. $1^{\text {st }}$, NW Washington DC 2000 $1-3710$.

Banwart, G. J. (1981): Indicator organisms in: In: Basic food microbiology. $2^{\text {nd }}$ ed. Avi. Publishing Co., Westport, Connecticut, USA.

Barkocy-Gallagher, T. M., Arthur, M., Rivera-Betancourt, G. A., E. D. Berry, Nou, X., Shackelford, S. D., Wheeler, T. L. , Koohmaraie, M. 2003. Seasonal prevalence of Shiga toxin-producing Escherichia coli $\mathrm{O}_{157}: \mathrm{H}_{7}$ and non- 157 serotypes and Salmonella in commercial beef processing plants. J. Food Protect. 66(11): 1978.

Barlow, R.S., Gpbious, K.S., Desmarchelier, P.M. 2006. Shiga toxin producing Escherichia coli in beef and lamb cuts. Inter. Food Microbiol. 11(1):105.

Bello, M.; Lawan, K.; Kwaga, J. and Abiola, R. (2011): Assessment of carcass contamination with $E$. coli $O 157$ before and after washing with water at abattoirs in Nigeria. International journal of Food Microbiology 150(23):184-186.

Bogere, P. and Baluka, A. S. 2014. Microbiological Quality of Meat at the Abattoir and Butchery Levels in Kampala City, Uganda. Inter. J. Food Safety, (16): 29-35.
Caprioli, A. S., Morabito, H., Bruge`re, E. Oswald. 2005. Enterohemorrhagic Escherichia coli: emerging issues on virulence and modes of transmission. Vet. Res. 36:289-311.

Clarence, S.Y., Nwinyi, O., Chinedu, S.N. 2009. Assessment of bacteriological quality of ready to eat food (Meat pie) in Benin City metropolis, Nigeria. African J. of Microbiol. Research, 3 (6): 390-395.

David, P., David, J., Stephan, M., Ian, J. , John, S. 2006. A National Survey of the Microbiological Quality of Beef Carcasses and Frozen Boneless Beef in Australia. J. Food Protect. 69(5): 1113.

Egyptian Organization for Standardization and Specification "EOS". 2005. For Fresh meat.

Eid, S.A.S., Erfan, A.M. 2013. Characterization of $E$.coli associated with high mortality of poultry flocks . Assiut Vet .Med. J. 59(139): 51-61, Egypt.

El-Bassiouny, A., Samaha, H. 1991. Role of abattoir effluents in contaminating carcasses with some food poisoning bacteria. Assiut Vet. Med. J. 25 (49): 108, Egypt.

El-Morsi, A. E. M. 1994. Sanitary status of buffalo-calf carcasses M.V.Sc. Thesis, Fac. Vet. Med., Zagazig Univ. Egypt.

Enabulele, S.A., Uraih, N. 2009. Enterohemorrhagic E. coli $0_{157 . H_{7}}$ Prevalence in meat and vegetables sold in Benin City, Nigeria. Afri. J. Microbiol. Res., 3(5): 276-279.

Ercolini, D., Russo, F., Torrieri, E., Masi, P., Villani, F. 2006. Changes in the spoilage-related microbiota of beef 
during refrigerated storage under different packaging conditions. Appl. Environ. Microbiol. 72 (7): 4663-4671.

Eugène, N.; Divine, B. and Martin, P. O. (2013): Assessment of beef meat microbial contamination during skinning, dressing, transportation and marketing at a commercial abattoir in Kigali city, Rwanda. PAK. J. Food Sci., 23(3): 133-138.

Fernández, D., Irino, K, Sanz, M. E., Padola, N. L., Parma, A. E. 2010. Characterization of Shiga toxinproducing Escherichia coli isolated from dairy cows in Argentina. Lett. Appl. Microbiol. 51(4):377-82.

Fliss, I., Simard, R.E. , Ettriki, A. 1991b. Microbiological quality of different fresh meat species in Tunisian slaughter houses and markets. J. Food Protect. 54:773-777.

Food Safety and Inspection service "FSIS" United States Department of Agriculture .1996. Pathogen Reduction; Hazard Analysis and Critical Control Point (HACCP) Systems; Final Rule. Federal Register/ Vol. 61, No. 144/ Thursdat, July 25.

Gill C. O., Bryant, J., Brereton, D. A. 2000. Microbiological conditions of sheep carcasses from conventional or inverted dressing processes. J Food Protect. 63(9): 1291-1294.

Hassouba, M. M. 2000. Prevalence of enteric pathogens in meat. Ph. D. Thesis, Fac. Vet. Med., Cairo Univ., Egypt.

Ismail- Eman, M. H. 2015. Improvement of Microbiological State of Menofia Abattoirs. M.V.Sc. Thesis (Meat Hygiene) Fac. Vet. Med. Moshtohor, Benha Univ.
Kaper, J. B., Nataro, J. P., Harry, L.T. 2004. Pathogenic Escherichia coli. Nat. Rev. Microbiol. 2:123-140.

Komba, E.V.G., Mkupasi, E. M., Mbyuzi, A. O., Mshamu, S., Luwumbra, D., Busagwe, Z. , Mzula, A. 2012. Sanitary practices and occurrence of zoonotic conditions in cattle at slaughter in Morogoro Municipality, Tanzania: implications for public health. Tanzania J Health Res. 14 (2): DOI: ttp://dx.doi.org/10.4314/thrb.v14i2.6.

Kuhnert, P., Boerlin, P., Frey, J. 2000. Target genes for virulence assessment of Escherichia coli isolates from water, food and the environment. FEMS Microbiol. Reviews (24): 107-117.

McFadden, J. F. 2000. Biochemical tests for identification medical bacteria. Warery Press Inc., Baltimore, Md. 21202 USA.

Malik, K., Memona, H. 2010. Molecular and immunological studies of pathogenic Escherichia coli in meat samples collected from different localities of Lahore. International J. Cell and Molecular Biol. (IJCMB), 1 (3) 218224.

Malorny, B., Tassios, P.T., Radstrom, P., Cook, N., Wagner, M., Hoorfar, J. 2003. Standardization of diagnostic PCR for the detection of food borne pathogens. Inter. J. Food Microbiol. 1 (25): 39-48.

Moustafa, M.M.M. 1993. Bacteriological studies on certain Gram negative food borne pathogens. Ph.D., Thesis, Military Institute of Health and Epidemiology, Military Medical Academy.

Nashid- Heba, F. 1993. Salmonella and Enteropathogenic E. coli serotype in 
meat and meat products. M.V.Sc. Thesis (Meat Hygiene) Fac. Vet. Med. Moshtohor, Zagazig Univ.,Benha Branch, Egypt.

Ram, S., Vajpayee, P., Hanker, R. 2007. Prevalence of multi antimicrobial-agent resistant, shiga toxin and enterotoxin producing Escherichia coli in surface waters of River Ganga. Environmental Science and Technology 41: 7383-7388.

Shawish, R. R. M. 2015. "Prevalence of shiga toxin-producing Escherichia coli in some beef products". Ph.D. Thesis (Meat Hygiene), Fac. Vet. Med., Menoufia Univ. (Sadat Branch), Egypt.

Sousa, C. P. 2008. "The Impact of Food Manufacturing Practices on Food borne Diseases". Brazilian Archives of Biology and Technology 51(4), 815823.

Tebbut, G. M. 1999: Microbiological contamination of cooked meats and environmental site in premises selling both raw and cooked meat products. Inter. J. Environ. Health Res. 3(4): 209216.

Wang, L., Li, Y., Mustapha, A. 2007. Rapid and simultaneous quantification of

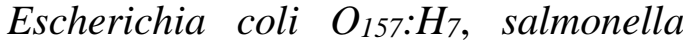
and shigella in ground beef by multiplex real-time PCR and immunomagnetic separation. J. Food Protect. 70(6):1366-1372.

Wang, X. G., Zhang, Y. H., Chen, X. H., Luo, L. F., Liu, Y., Liu, J. Q., Song, C. P., Chen G. Q. 2013. Establishment and application of multiplex PCR for non-0157:H7 STEC virulence genes detection. Zhonghua Shi Yan He Lin Chuang Bing Du Xue Za Zhi. (Article in Chinese)., 27(5):388-91. 